УАК 930.2

001.5:930

doi: 10.5937/bastina31-31917

Originalni naučni rad

\author{
Dragan LJ. TANČI Ć \\ Institute of Serbian Culture Priština - Leposavić \\ Dalibor M. ELEZOVIĆ $* *$ \\ Faculty of Philosophy, Kosovska Mitrovica
}

\title{
HYPOTHESES IN HISTORICAL RESEARCH
}

\begin{abstract}
In all sciences, there is a general agreement that hypotheses can be defined under the rules of scientific defining. Consequently, with most authors in different sciences and scientific disciplines, it is indisputable that there is a general agreement of different theoretical and methodological directions that hypotheses are based on assumptions about the phenomenon, problem, and subject of research, which are expressed in the form of attitudes and judgments and have some cognitive value, in all sciences as well as in historical research. Hypotheses are determined by the definition of the problem, the subject of the research, and the goals of the research, primarily scientific ones. Hypotheses in all sciences, even historical ones, consist of variables and attitudes of a hypothesis that expresses the relations between variables. It is necessary to distinguish hypotheses in the process of acquiring scientific knowledge and in scientific research projects.
\end{abstract}

Key words: history, historical phenomena, scientific and historical research, hypotheses.

\section{INTRODUCTION}

Having in mind the title of this scientific paper, it is necessary to define the concept of history, historical phenomena, scientific and historical research at the very beginning, and only then scientifically process the concept of hypotheses and bring them into the necessary relations, ie relations with historical research. History as a phenomenon, reality, science, is very complex and its content during the development of human communities has been constantly changing, supplementing, harmonizing about the overall social, political, and other relations and influences in the past and different areas. History as a science bases its

* Associate Professor, dragan_tancic@yahoo.com

** Associate Professor, dalibor.elezovic@pr.ac.rs 
scientific knowledge on a critical study of material and spiritual creations, written sources, and oral traditions about events in various spheres of human life. The subject of history is people and their creations and their development, which means that there is no history without people as social and political beings, or parts of a certain community, in a certain time, space, and territory.

\section{DEFINING CATEGORICAL TERMS OF THIS PAPER}

There are many definitions of history in the scientific-theoretical fund, created in different periods of historical and scientific development. Inspecting these sources, we can conclude that there is an indisputable existence of many agreements - disagreements, but we can see a general tendency to emphasize partial, individual approaches in defining history, which emphasize some definitions of the concept of history. Accordingly, a general approach is missing, which would include all the essential definitions of the concept of history and classification criteria based on which a general definition and general and specific criteria for the classification of history and historical phenomena could be given.

As a general definition of history, we will give a general definition given by D. Tančić: „History is the science of the past of human society, with its subject and method, which bases its knowledge on a critical study of material and spiritual creations, written sources, and oral traditions, events in important areas of nature and society, in a certain time, space, and in a certain territory, in the recent or distant past. The basic premise of the existence of human history is the existence of people, in certain conditions, with their needs, motives, interests and goals, actions and deeds, who realize their needs and activities within the social division of labor, in a certain production process, within certain social and political communities, by applying various methods, which achieve certain results, effects and consequences" (Tančić 2009: 166).

The concretization of history is realized through historical phenomena. According to Tančić, „under historical phenomena, in a broader sense, we can consider all natural, social and political and other phenomena of the past, which were based on different situations and which are manifested in various spheres of natural, social, political and other processes. and in various ways, where the central factors are the subjects of historical phenomena of people, various roles, activities, actions, and deeds. Basically, historical phenomena include important historical processes, structures, systems, activities and actions, methods, means, results, effects, and consequences in the sphere of human real life and the sphere of human, historical, consciousness in the recent and distant past. This definition of historical phenomena should be understood conditionally 
because human consciousness is part of the overall human reality" (Tančić 2009: 167). Important properties of historical phenomena are dynamism, processuality, development, purposefulness, organization, but also spontaneity and disorganization. They are also certain historical behaviors, a set of many activities, actions, deeds, and actions. Historical phenomena include natural, social ones $^{1}$, political ${ }^{2}$, legal, economic, cultural, technical-technological, military, religious and other phenomena, in the recent or distant human past. ${ }^{3}$

The question arises (given that we have explained the basic categorical terms in this paper in the previous section) whether it is possible, and in what way, to scientifically research historical phenomena? Namely, having in mind our definition of historical phenomena, we believe that they can be researched both interdisciplinary and intradisciplinary, within the natural and social sciences, but also within several sciences. For example, some historical phenomena, which are at the same time social, political, and military, can be researched from the historical, political, legal, economic, or military aspect, but also the aspect of other sciences and scientific disciplines. In this context, we must explain the concept of scientific and historical research, and then process hypotheses in historical research. First, what we must emphasize (and often scientists forget about it) is that scientific research always refers to the subject of science, sciences, or scientific disciplines.

Scientific research includes the theoretical, empirical, and methodological approach, theoretical considerations at the beginning which aim to build a theoretical concept and model and check the theoretical concept and model with the "theoretical“ and "empirical and methodological model“ and data, inference based on them and activation of overall practices based on scientific knowledge, and again theoretical treatment as verification, supplementation, extension and development of new hypotheses and theories. Under historical scientific research can be understood systematized, objective and critical processes of acquiring new scientific knowledge about the recent or distant past, in which the roles of scientific knowledge and the overall past as a practice change ${ }^{4}$.

1 „According to M. Weber, we define the essence of a social phenomenon „as ..... the essence of a social phenomenon", „social actions“ ... as the behavior of individuals that has an inner meaning, meaning for participants and which is directed towards the behavior of another individual. The essence of the social phenomenon is therefore an expression of a subjective character ... The social phenomenon is, therefore, a unique, unrepeatable cultural-historical phenomenon" (Pečujlić 1976: 35-41).

2 „There are two basic areas of political phenomena: the area of real human life and the area of human consciousness" (Milosavljević 1980: 44).

3 The stated division of historical phenomena is based on the criterion of generality, and according to some on the criterion of content.

4 Gian Antonio Gilli defines research as: „research is a) cognitive activity of analysis and reasoning, b) that takes place in practice, c) on a practical and real problem, and d) precedes a certain intervention in reality" (Gilli 1974: 12). 


\section{PROBLEMS OF THE SCIENTIFIC DEFINITION OF HYPOTHESES}

To investigate a phenomenon, process, problem, it is necessary to start from something, and therefore it is necessary to keep in mind some assumptions about the phenomenon, problem, and subject of research that we intend to realize. In this context, the question arises: Can we define hypotheses and how? The answer is yes. Yes, hypotheses can be defined according to the rules of scientific definition. Namely, in the scientific fund, there is a general agreement among many authors of different theoretical and methodological directions that hypotheses are based on assumptions about the appearance or part of a phenomenon, process, problem, and subject of research, expressed in the form of stands - judgments. If those assumptions are grounded and if they have a certain cognitive value, then the hypotheses have the form of judgments; and if they have only a postulated cognitive value, their form is attitudes.

In the research project and the draft scientific idea, the hypotheses are scientifically based and have the form of judgments (simple, single or interconnected, connected multiple) because their content is based directly on the subject of research and indirectly on the definition of the problem, ie. on his basic hypothetical views. The level and direction of hypotheses are determined by the goals of research, primarily scientific ones. So, in the research project, the draft of the scientific idea, the hypotheses are derived from the formulation of the problem, the subject of the research, the goals, and form a system that is correlated, reciprocal and proportional to the subject and goals of the research. The stated relations of the relation of hypotheses or system of hypotheses, according to the previous parts of the project, draft scientific idea, arises from the fact that the operational determination of the subject communicates all important variables, and hypotheses consist of variables and attitudes of the hypothesis that expresses the relationships between variables. It is necessary to point out these relations between hypotheses and previous parts of the research subject because in the methodological literature there are contradictory views on the place and role of hypotheses. After all, hypotheses in the process of acquiring scientific knowledge generally do not differ from the hypotheses in a scientific research project.

There are many definitions of hypotheses in the scientific fund. For example, some researchers in the historical sciences, humanists in the 16th century, defined hypotheses that were in the form of assumptions as starting points, based on unproven prejudices. Consequently, they started from the initial assumption, sought an answer, and finally, based on a subjective assessment, determined whether their premise provided a satisfactory answer (Glass, Hall 2008: 378). One of the most famous works on the topic of the relationship between 
science and hypothesis is the work of Henri Poincare "Science and Hypothesis" from 1917 (Poincare 1917). Cuba and Koking argued that hypotheses should be constructed to show that they are false or potentially inaccurate so that if a researcher finds that his observations support the initial hypothesis, it is valid; if the observations contradict his hypothesis, he must look for an alternative formulation (Cuba, Koking 2003: 136). Shibashina believes that hypotheses are a special form of scientific approach and their use in science provides an opportunity to move from separate scientific facts related to the phenomenon, to their communication and knowledge of the laws of development of this phenomenon (Шибаршина 2011:124-126).

We will, following the requirements of this level of scientific processing, give several characteristic definitions:

1. „Hypothesis represents what we predict“;

2. „A hypothesis is a question that is formulated in such a way that a certain answer can be given on it in a certain way";

3. „A hypothesis is an attitude that can be subjected to a test to determine its validity";

4. „Hypothesis is a mental assumption about the subjects being researched“;

5. „A hypothesis is a statement of a certain subject meaning and presumed cognitive value that has yet to be tested". 5 .

6. „Hypotheses are thought-theoretical additions to certain gaps in the knowledge of a certain phenomenon or an entire area of phenomena whose certain moments, parts, or aspects we already know" (Zaječaranović 2009: 187-190).

7. A hypothesis is "a statement that can be put to the test to establish its validity,"

8. "In practice, a theory is an elaborated hypothesis that deals with more types of facts than a simple hypothesis ... The difference is not clearly defined."

9. "A hypothesis is a necessary link between theory and research that leads to the discovery of new knowledge" (Gud, Het 1966: 56-57).

10. „Hypotheses are an established mental assumption about the subject of research as a whole, its factors, properties, relations and connections, situation, dimensions, essence, content, and form",

11. Hypotheses are "theoretically grounded, thought-based subject assumptions that have yet to be proven by research results" (Milosavljević 1980: 97).

From the above definitions, we notice different theoretical and methodological approaches of many authors. Thus, Karl Popper in his scientific monograph fifty years ago ("Logic of Scientific Discovery" from 1973), states that hypotheses are networks, and whoever throws them, will catch something, which means that only the one who sets the hypotheses has a chance to solve some problem

5 The given definitions of hypotheses from 1 to 5 are taken from: (Šešić 1978: 208). 
or phenomenon, to explain them and to master them. On the other hand, a wellknown Serbian scientist, Ajdačić, asks a justified question: Can it be researched without hypotheses? At the same time, he answers, and points out - sometimes even „a blind hen stumbles upon a grain“, or, b) cannot (Ajdačić 1990).

Long ago, Bacon held the view that the hypothesis was at the beginning of the cognitive process. Without going into an essential analysis of the reasons and validity of this relatively widely accepted view, we must challenge its validity for the hypotheses in the research project. The arguments are: a) hypotheses are based on attitudes - judgments, not arbitrary assumptions. They are based on existing usable knowledge; b) hypotheses are not „empty” views, but objective ones. This practically means that the content of these attitudes refers to existence, condition, etc. the subject about which the true knowledge is to be acquired; c) the source of hypotheses is previous knowledge and gaps, shortcomings or gaps in them or discovered possibilities - which is reached by theoretical or empirical research or some other process of cognition. In short, hypotheses are always assumptions about something, and they cannot be formed about nothing. So, hypotheses are preceded by some knowledge (even a perception of which there is awareness) about which one thinks, so the hypothesis appears as a result of thinking about something known.

In scientific and historical research that requires the development of a research project, neither the conceptualization nor the design of research begins with the definition of hypotheses, but with the ascertainment of phenomena and problems related to a given phenomenon or phenomena. Thus, e.g. among some reasearchers sociologists have formed the view that we are „investigating a problem, not a phenomenon". So the content of the hypotheses would be a problem! However, this approach is incorrect because both the problem is a social and other phenomenon and it is only a conglomeration of various phenomena in specific relationships which cause social discomfort. However, we investigate certain phenomena (or phenomena), i.e. that part of them, aspect, etc. which we defined as a subject of research, and the content of hypotheses (variables and position of the hypothesis) refer to the subject of research.

\section{HYPOTHESIS CLASSIFICATION}

There are various hypotheses and they are classified according to various properties, the most common of which are:

1) subject; 2) logical nature; 3) generality and 4) cognitive role of hypotheses.

According to the subject, we distinguish a) theoretical hypotheses, which refer to theoretical subjects, and are formulated most often in theoretical research. However, some empirical research can be completed by setting new hypotheses, and they can be and often are theoretical; b) empirical, whose 
content relates to social reality and which most often occur in empirical research; c) methodological, and d) illusory, whose contents do not refer to the objects of social reality and which are wrong, dysfunctional, because they cannot be verified. Within the criteria of the subject of hypotheses, we also find a dichotomous sub-criterion: a) qualitative hypotheses - whose contents are the qualities of the phenomenon - its structure or composition, its properties, relations, and connections, division, etc.; b) quantitative - whose contents are quantities-sizes, volumes, masses, durations, frequencies, sequences, etc. expressed either verbally (earlier, larger, heavier, longer, more frequent) or numerically; c) mixed qualitative-quantitative hypotheses, which can be considered very common. This approach obliges us to always keep in mind that each quantity is only some kind of amount - a dimension of quality. The „logical nature of hypotheses" criterion also contains two sub-criteria. The first expresses the logical process of hypotheses and according to it we distinguish: a) simple-implicative; b) inductive; c) deductive and e) statistical - which do not have to be exclusively quantitative. The second sub-criterion is the modality of the judgments by which hypotheses are expressed, and therefore we have: a) possible; b) probable and c) accidental. The hypotheses in the research project are characterized primarily by implications and probable hypotheses. The third general criterion contains two sub-criteria. The first is the coverage of the matter, and within it: a) general hypotheses and, as their specific form, general hypotheses; b) special hypotheses whose content is already covered by the general hypothesis, but which by a special hypothesis specifies and concretizes the position on the segmental factor (segmental factors) of the case; c) individual hypotheses, the content of which refers to the elementary factors of the subject of research. These are the most concrete hypotheses and through them, a direct connection is established between the variables and attitudes of the hypotheses on the one hand and the indicators on the other. The second sub-criterion requires a distinction between the general validity of hypotheses and distinguishes: a) hypotheses of empirical uniformity and regularity; b) hypotheses of statistical generalization; c) hypotheses of rational analytical variables. All three types of hypotheses, and in some studies all three types simultaneously can be found in the same study, especially in the empirical one. The cognitive role, as a classification criterion, also contains two sub-criteria. The first is the function in the research activity according to which hypotheses arise: $a$ ) ad hoc; b) working - which are typical for research projects; c) auxiliary; e) elaborative and e) scientific hypotheses (which were formed as a result of scientific research, ie. as "post hypotheses"). Auxiliary and elaborate hypotheses are just outdated terms for special and individual hypotheses in a research project. The second sub-criterion is the scientific goals of the research, and according to them we have: a) descriptive; b) classifiers; c) heuristic; e) explicative (causal), and e) prognostic. 


\section{DERIVATION OF HYPOTHESES}

In all types of scientifically valid research projects, hypotheses of different degrees of generality necessarily appear about each other and with their own special functions. As a general rule, for each degree of generality of the operational determination of a case, one or more hypotheses are set or derived, depending on the properties of the operational determination of the subject and the degree of their dilution, and consequently, a general or universal hypothesis must be derived which has to include the whole of the research subject and express a general position on unknown or scientifically unverified features and factors of the subject of research. This is the rule that applies to simple, interdisciplinary research, which is the most common, ie. to projects and drafts of scientific ideas of simple research. Specific rules apply to complex and interdisciplinary research projects. In one simple research project, one general hypothesis must be set up, which is the starting point and the basis for deriving hypotheses of a lower level of generality.

Hypotheses are derived from the definition of problems, subjects, and research goals; b) hypotheses of a lower degree of generality from hypotheses of a higher degree of generality. From the segmental parts of the operational determination of the subject of research and the general hypothesis, special hypotheses are derived. Their content expresses a special attitude (or attitudes) about the content of a certain segment that can be understood as a separate, complete part of the operational subject of research and the part of the general hypothesis that refers to that segment. Special hypotheses are simultaneous and concretized, a specialized part of the general hypothesis and a special, hypothetical position on a special segment of the operational determination of the subject. Individual hypotheses are derived from the elementary factors of the operational determination of the object and special hypotheses - their parts that relate to a certain elementary factor. In this three-step system of hypotheses, individual hypotheses are the most specific. They are the direct link between objects, hypotheses, and indicators (Milosavljević 1980: 107).

The scientific goals of the research project determine the levels of the hypothesis so that if the scientific goal of the research is a scientific explication, the content of the hypotheses must refer to cause-and-effect relations, scientific laws, and scientific explanations. Perceptions of the null hypothesis may be inconsistent. Some methodologists do not process hypotheses at all or see them in research practice. An example is J. D. Fitzgerald, S. M. Fox in „Research Methodology in Criminological Sciences", do not mention hypotheses at all, but immediately go from ,identifying units of analysis" and from "defining concepts" to presenting variables. (Fitzgerald, Steven M. Fox 2001: 36-38).

The basic features of hypotheses are a) verifiability, which means that they are suitable for proving and confirming, as well as for refutation b) probability 
- they must be to some extent probable, not just possible; c) scientific knowledge; e) adequate and proportionate. Hypothesis statement must be meaningful, it must contain - express an opinion, judgment, etc. about the subject of research or only about one of its parts; b) it must be subject-specific and strictly defined; c) the statement must be clear and precise, and the terms used unambiguously in the given context; $d$ ) the statement must be properly dimensioned. And the position of the hypothesis must correspond to certain norms that prescribe that it be: a) scientifically-cognitively significant; b) scientific-problematic; c) logically inconsistent in the theory to which it belongs and in the theoretical model of the project or draft scientific idea; d) to express differences, contradictions, and contradictions within the model of drafting a scientific idea; e) expressed in the language inherent in the respective science - scientific discipline.

The general functions of the hypothesis are a) elimination of gaps in the existing scientific knowledge; $b$ ) overcoming and eliminating contradictions within and between individual parts and factors of scientific knowledge; c) achieving a higher level of scientific knowledge.

When we talk about the process of deriving hypotheses. S. Milosavljević and I. Radosavljevic in the book „Fundamentals of the methodology of Political Sciences" define what is related to a certain subject - subjects factor remained uncovered by scientific knowledge or what has not been yet verified; 2) from the existing scientific knowledge, those parts that make up the theoretical whole, the necessary attitudes are deduced; starting from partial, individual knowledge, they are induced; 3) based on that, variables of concepts-attitudes are selected, subject constants are assigned to them, subject statements are formed and interconnected by logical statement functions (Milosavljević, Radosavljević 2000).

\section{HYPOTHESIS STRUCTURE}

Hypotheses are well-founded assumptions about the subject of research and they must always have a certain structure, which consists of at least one independent and one dependent variable and a certain relationship between them, which is expressed as the position of the hypothesis. According to the role of variables in hypotheses, we distinguish between independent variables that we denote by $\mathrm{X}$ and dependent variables that we denote by $\mathrm{Y}$. The role of an independent variable is to show the cause, reason, etc. of the dependent variable and to describe it. The dependent variable shows the consequences of the action of the independent variable. In addition to the independent and dependent variables, the hypotheses may also include variables in other roles: a) antecedent or explanatory, which explain the independent and dependent variable, ie. the correlation between them; $b$ ) intervening or interpretive variables, which explain 
the reasons for the existence of a relationship between the independent and dependent variable, and c) connecting or specific, which expresses the intensity of the conditions of the relationship between the independent and dependent variable. According to the content, we distinguish a) qualitative and b) quantitative variables. Qualitative variables express variable properties, forms, relations of occurrence, or factors of occurrence, while quantitative variables express dimensions, quantities, frequency, and other quantitative provisions. In the same hypothesis, they can perform various roles, both qualitative and quantitative variables. Which variables will be included in the composition of the hypothesis depends on the operational and theoretical determination of the subject. For example, the readability of X Magazine, its cultural section, cannot be explored without quantifying concepts. The very statement "satisfactory readability” implies that of the possible readers, of which there are a) readers of magazine $\mathrm{X}$ in total, $\mathrm{b}$ ) possible readers. The quantitative variable does not have to be expressed exclusively numerically but also verbally by "quantitative terms and conditions" such as little-much, more-less, growth-decline, before-after, etc.

When talking about hypotheses, indicators must always be kept in mind. These are in fact manifestations of a phenomenon, direct or indirect, which can be recorded and recognized by the senses and through which true and verifiable knowledge of that phenomenon can be acquired (Županov 1962: 46-60; Šešić 1980: 200). Only phenomena that are manifested in some way can be investigated because really only the manifestation allows intersubjective verification.

It should be added to the definition of indicators that indicators in a scientific research project are not any manifestations, but only those that refer to the structure of the hypothesis - primarily to its position - and in the meaning that corresponds to the conceptual-terminological and semantic system. The reason for this is that this same manifestation of one phenomenon in different situations, in different research projects, at different times, and in different spaces can have different meanings - especially for different social subjects. For indicators to be indicators, they must be clearly defined and the realities to which certain terms refer must be described - i.e. the realities that and by which they are shown. The indicator shows what is shown by the manifestation. In connection with our already mentioned example, it could look like this: Magazine Y writes five times in its column over seven days about one political excess, conflict, attitude, or action. Is that an indicator? Of course, this is a quantitative simple indicator for the frequency of certain topics in articles. And is it an indicator for impartiality - the bias of the subject section or its consistency, adherence to principles, etc.? No, that fact alone is not a valid indicator for that, although it is a significant component of the indicator. To form a valid indicator for bias impartiality, it is necessary to add indicators for the orientation of the article, the views expressed, the authors of the views, sources of knowledge, evaluation, etc. 
So, there is no possibility to form one simple indicator, but a complex indicator is needed. Further, the indicator refers to the position of the hypothesis. Indicators do not have the same value, and their value is determined for each project, even for each hypothesis (in exceptional cases). However, the same imperative applies to all indicators: to be valid, which includes: a priori validation, logical validation, validation by jury opinion, and validation of indicators by known groups. In essence, the characteristics of valid indicators are a) objectivity; b) reliability; c) unambiguity; e) precision and e) representativeness.

Indicators are usually classified according to content criteria - indicators of variables and indicators of hypothesis attitude; validity criterion: usable and unusable, ie relevant and irrelevant indicators; the criterion of origin: expressive (indicators of attitudes) and predicative (indicators of real dimensions - properties); criteria of complexity - elementary (simple) and syndromic (complex, connected in a meaningful whole simple) indicators. The choice of indicators depends on the necessary true, adequate data that confirm or refute the hypothesis, as well as on 1) the nature of the subject and objectives of the research; 2) characteristics of hypotheses and variables, and 3) previous scientific knowledge about the subject of research.

\section{LITERATURE}

Ajdačić 1990: Vladimir Ajdačić, Science as a fairy tale, Gornji Milanovac, Dečije novine.

Бориснёв 2010: Сергей Бориснёв. „Современные проблемы теории и методологии исторического исследования“, Армия и общество, (3), 81-87.

Fitzgerald, Fox 2001: Jack D. Fitzgerald, Steven M. Fox. Research Methodology in Criminological Sciences. Sarajevo: Faculty of Criminological Sciences.

Gilli 1974: Gian Antonio Gilli. How to research. Zagreb: Školska knjiga.

Glass, Hall 2008: David Glass. Ned Hall. „A Brief History of the Hipothesis“. Cell, Vol. 134, (3), 378-381. doi.org/10.1016/j.cell.2008.07.033

Gud, Het 1966: Viliam Gud, Pol Het. Methods of social research. Belgrade: Vuk Karadzic.

Jordan 2009: Stefan Jordan. Theorien und Methoden der Geschichtswissenschaft. Paderborn: Ferdinand Schöningh.

Knoepfel, Larrue, Varone, Hill 2011. Peter Knoepfel, Corinne Larrue, Frederic Varone, Michael Hill, „Research and working hipotheses“. Public Policy analysis, 251-270. DOI:10.1332/policypress/9781861349071.003.0011

Kuba, Koking 2003: Li Kuba. Džon Koking. Methodology of making a scientific text. Podgorica: Cid.

Milosavljević 1980: Slavomir Milosavljević. The study of political phenomena. Belgrade: Institute for Political Studies, Faculty of Political Science.

Milosavljević, Radosavljevic 2000: Slavomir Milosavljević, Ivan Radosavljevic. Fundamentals of the methodology of Political Sciences. Belgrade: Službeni glasnik.

Pečujlić 1976: Miroslav Pečujlić. Introduction to Sociological theories- Proceedings, Fundamentals of social science, IV edition. Belgrade: Službeni list.

Poincare 1917: Henri Poincare. Science et hypothese. Paris: Flammarion. 
Šešić 1980: Bogdan Šešić. Basics of the methodology of social sciences. Belgrade: Naučna knjiga. Шибаршина 2011: Светлана Шибаршина. „Гипотеза в социально-гуманитарных науках“, Вестник Нижегородского университета им. Н. И. Аобачевского. Серия: Социальные науки, књ. 2, (22), 124-130.

Tančić 2009: Dragan Tančić, The historical method in the research of political phenomena, doctoral dissertation defended at the Faculty of Political Sciences in Belgrade, University of Belgrade.

Zaječaranović 1977: Grigorije Zaječaranović. Fundamentals of the methodology of science. Belgrade: Naučna knjiga.

Županov 1962: Josip Županov. Indicators; in the collection Methodology of Research in Social Sciences. Belgrade: Institute for Criminological Research. 
Араган $\triangle$. ТАНЧИЋ

Аалибор М. ЕАЕЗОВИЋ

\section{ХИПОТЕЗЕ У ИСТОРИЈСКИМ ИСТРАЖИВАҢИМА}

\section{Резимe}

Под историјским научним истраживањима могу се схватити систематизовани, објективни и критички процеси стицања новог научног сазнања о ближој или Аањој прошлости, у коме се улоге научног сазнања и укупне прошиости као праксе смењују. У свим наукама постоји општа сагласност, Аа се хипотезе могу дефинисати у складу са правилима научног Аефинисања. САеАствено томе, коА већине аутора је неспорно постојање опште сагласности различитих теоријско-методолошких праваца, Аа су хипотезе основане претпоставке о појави, проблему и предмету истраживања, које су исказане у облику ставова и судова и Аа имају одређену сазнајну вредност, у свим научним, као и у историјским истраживањима. Хипотезе су опредељене формулацијом проблема, предметом истраживања и циљевима истраживања, и то пре свега научним, састоје sе из варијабли и ставова хипотезе који исказују односе између варијабли. Хипотезе је нужно разликовати у процесу стицања научног сазнања и у пројектима научног истраживања.

Кьучне речи: историја, историјске појаве, научна и историјска истраживања, хипотезе.

РаА је преАат 20. априла 2021. године, а након мишьења рецензента, оАлуком оАговорног уредника Башитине, одобрен за штампу. 